\section{第19回 九州歯科学会総会}

昭和 34 年 5 月23、24日 於本大学

\section{講演}

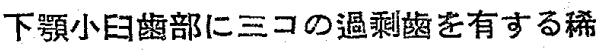

有なるー例

(口) 解) 山田 博、空閑平治

現在人類荘牙はその数を減して所謂退化傾向を示し ているが、これとは反対に人類橉牙の定数を超過して 過剩歯の出現を見るとともある。過剩歯の出現は概し て上顎前歯部に多く、次で大画部に多く認妨れ、 小曰霜部には比較的少いとされている。

今回私共は某歯科医の方より本教室に笴贈いただい た多数の石膏模型を整理中に隅々下顎小曰歯部に三コ の過剩雪を有する模型を発見し、し加も何れも大き さ、形態ともに殆んど正常なものと変らない所見を呈 していたので、それを茲敢て報告する次第である。

本人は健康にして家族の中に過剩歯を有するものは ない。年令は21才の男性てして下顎の全䨑牙32本は全 て萌出している。左側小曰藏部は正常の小曰雨が二コ 歯列上に立び、ての舌側そ二コの小曰歯と同型の歯牙 が前後に立んで丁度四コの小雪が存在している。一 方右側は同しく正常小曰歯が二コ䨑列上亿存在し、第 二小曰歯の舌側薏心部に一コの小崡が萠出して計三 コの小四が存在している。即ち左右併せて七コの小

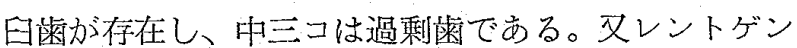

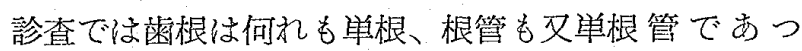
た。

これら過剩崡の出現については隔世遣伝の説、或は 進化過程に预ける復古現象であるとする説、さらに又 過剩蒾胚の出現によるもの等々諸説があつて一定しな いが、藤田氏の説く如く䨑提に和ける何等汃の形態的 攪乱による過剩霜肧の出現によるものではなからうか と考えられる。

\section{大動脉弓最終枝としての右䥊骨下動脉の 一例に就て}

(的剖) 大森忠雄

(1) 本例に和いては腕䫟動脉を欠いでいる。

（2）大動脉亏は 4 個の大なる動脉を各個独立して分 枝せしぬている。
録

（3）大動脉弓の最終枝として右鎖骨下動脉を出して いる。

以上 3 つの特長を有す。な打本例に初いては他の 動、静脉ならびそ神経等には著しい異常は認めない。 犬の顎関節軟骨並びに関節円板の発蔏に 伴う分裂線の変化に就て

(解，部) 野見山谈光 古く汃ら分裂線法による組織の線維棈築に関する研

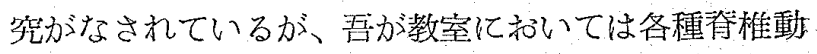
物の骨分裂線低関する系統的、比較解剖学的研究をな し骨分裂線は各時期认扔ける骨の発育樣相を現わすも ので、その線系は骨の発育方向索、不整裂線は乱れと して骨緻密質の直接的機能表現であるととを明らかな らしぬている。

然らば軟骨に打いても分裂線の変化を以て骨緻密質 に扣けると同溙の意味付けが行えるかとの観点に立 ち、又顎の機能状沅と発育との関係を分裂線上より明 らかならしめたいため、犬を用いて顎関節軟骨並びに 関節円板の発育に伴う分裂線の変化を実験観察した。

実験に使用した犬は日本犬雑種赤毛短毛の雄の及を 使用儿、胎伱 60 日、生後 1 力月、 2 力月、 3 力月、 5 力月、 7 力月、 9 力月、 1 年、 2 年、 3 年、 5 年、 7 年及び 9 年の 13 年令期である。その結果を要約するに

（1）そ礼ら分裂線の状沅は全時期を通じて見るとき 加令的形態変化と生活機能の䘽猚化に相応した一連の 変化として把握出来る。

(2) $\triangle$ 第 1 期（胎仔 60 日）発育前期にして不整裂線: 団のみ学認める。 $\triangle$ 第 2 期（生後 1 力月～生後 5 力 月）将来の基本的 2 個の線系を認め極めて旺盛な生長 発育期で外側部に扔ける上下方向ならびに内側部にお゙ ける内側端中央より前、後両縁に向う発育の著明な線 系が出現し、且つそれらの発育方向の乱れによる不整 裂線団ならびそ阻㗖機能発現を想わせる不整裂線団の 出現を見る。 $\triangle$ 第 3 期（生後 7 力月～生後 1 年）生 長完了期にして第 2 期と同様の発育方向を示し活発な

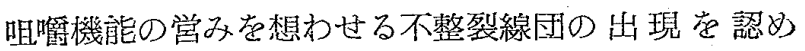
る。 $\triangle$ 第 4 期（生後 2 年 生後 5 年）生長完了乙生 活機能就中咀嚼機能の旺盛な時期で、線系の配列の乱 れさらに恢復による整然たる配列觉繰返す。 5 期（生後 7 年 生後 9 年）萎縮発現の時期で線系が 寧ろ不整化する。 